\title{
Binomial Analysis of the Demand for Higher Education in Borno State of Nigeria
}

\author{
JIBIR. M. Talba ${ }^{1, *}$, Bello Ibrahim Alhaji ${ }^{2}$, Moussa Ibrahim ${ }^{3}$ \\ ${ }^{1}$ Department of Economics, University of Maiduguri Pmb, 1069 Maiduguri, Nigeria \\ ${ }^{2}$ Department of Economics, North West University Kano, Nigeria \\ ${ }^{3}$ Department of Sociology and Anthropology, University of Zinder, Niger Republic \\ *Corresponding author: mtdjibir@gmail.com
}

\begin{abstract}
Demand is a multidimensional and determined by many factors. Education is viewed as investment and key to development of any nation. This paper investigated the demand for private education in Nigeria with focus on Borno State. Both primary and secondary sources of data were utilized in this paper. The primary data were obtained from random administration of 2000 questionnaires to 5 enumeration areas. The paper extensively used probabilistic sampling techniques to get the data ready. The living standard measurement Surveys was also utilized in collecting data. The probit regression technique was used to assess the impact as well as determinants of higher private education for rural households, urban households and combinations of both variables. The result shows that the size of households, per capita spending, school fees, father's level of education, households location in the rural or urban areas, and intermittent strikes of university teachers constitute the main determinants of higher education demand in Borno state. Note that high increase in the demand for higher private institution in Borno state can be attributed to the influence of institutional, economic and socio cultural factors. The paper recommends that some measures should be put in place by educational planners to emphasize the quality of output from the higher public and private institutions. There is also need to match the candidate choice of course and the marketability of the course in the labor market. This paper also note that school fee is never an impediment to choosing the private higher institution, Therefore user charges could be used to address poor funding of public institutions in Nigeria. Policy makers should look into agitations of lecturers in tertiary public institutions in order to address the teething problem of inadequate funding of public institutions to avoid brain drain and further falling standard of education in Nigeria.
\end{abstract}

\section{Keywords: binomial regression, backward linkages, forward linkages, higher education}

Cite This Article: JIBIR. M. Talba, Bello Ibrahim Alhaji, and Moussa Ibrahim, "Binomial Analysis of the Demand for Higher Education in Borno State of Nigeria." American Journal of Educational Research, vol. 5, no. 6 (2017): 677-682. doi: 10.12691/education-5-6-13.

\section{Introduction}

The economic value of education in terms of higher wage income for highly educated individuals) has been hotly debated in economic literature ever since the classical economists. With the advent of human capital theory, the correlation between education and income became more pronounced. Proponents of human capital theory view education as investment and the bedrock for economic development.

Education is seen as a private and social investment that is shared by individuals, households, communities, as well as government and other groups. A household may be a consumer, producer or wage income earner. The higher the level of education of individuals or household members, the higher is the wage income earned and the better is the productive capacities of the households or individuals under consideration. Higher education equips individuals or households with new attributes, skills, technical expertise required to achieve the objective of the organization. Education is achieved through different academic institutions like universities, polytechnics, monotechnics, and colleges of education and in any post secondary institutions. Thus, these institutions yields direct and indirect marginal benefits to individuals, communities and households.

Recently, many economies in Sub-Saharan Africa and latin America witnessed a growth in the demand for higher education as confirmed in economic literature. Basically, we can summarise the main determinants of demand for higher education into two: (1) income and employment expectations relevant to each level of education and (2) the family background characteristics of each potential students $[2,5]$.

The increase in the demand for higher education and the inability of the government to meet up with the demand due to endogenous problems facing tertiary institutions has been a concern for academics, educationists, policy makers and government at various levels. According to

Okuwa [5] over the past decades the demand for higher education in Nigeria has risen considerably, about 60 to 70 percent of all secondary school leavers continued their studies beyond secondary level. However, various factors 
contributed to the increase in the demand for higher education after independence In Nigeria.

Amongst these factors are the broad societal changes (emancipation an d empowerment of women, gender mainstreaming), education policies, economic, social and cultural factors as well as the Millennium Development Goals that call for educational improvement and reduction in level of illiteracy worldwide.

Okuwa [5] has conducted similar study in Ibadan Oyo state using revealed preference principle. There is paucity of research in terms of coverage, methodology, as well analytical techniques necessitating needs for a more plausible research in the area. To our knowledge there is no comprehensive study on the demand for higher education in Borno State, this leaves a knowledge gap needed to be filled in. This paper is to investigate the determinant of the demand for higher education in Nigeria with a special focus in Borno State. The paper attempts to answer the following questions:

i. What are the determinants of the demand for higher education for rural households in Borno state?

ii. What are the key variables for urban households demand for education in Borno State?

iii. Is there any relationship between choice of the course and likely performance of the candidate?

iv. To what extent did the educational attainment of parents affect the demand for higher private education in Borno State?

v. How do backward and forward linkages affect the demand for higher education in Borno?

The rest of this paper is organized as follows: Section 2.1 examines the reasons for the increase in private higher education over time and space in Nigeria. The subsequent section presents the literature review and theoretical framework. Section 2.3 presents the methodology, while section 2.4 addresses the results and discussion. The last section addresses policy implications of findings and offer recommendations.

The Nigerian educational system is made up of colleges of education, polytechnics and universities, owned by both state, federal government and private individuals. In 1932, the British Government established Yaba Higher College in Lagos as the first higher educational institution in the country. The University College, Ibadan was established in 1948 based on the recommendation of the Asquith and Elliot Commission in 1945. This was followed by the establishment of University of Nigeria, Nsukka in October 1960 as the first regional university.

As a result of Asby Commission report, three more universities were established in Lagos, Zaria and Ife. By 1962, the Nigerian higher education consisted of three regional universities and two federal universities. By 1972, it increased to six universities with the addition of University of Benin established by the Mid-western Region Government at that time (Taiwo,1986). In 1975, seven more universities were established at Jos, Maiduguri, Sokoto, Kano, Illorin, Calabar and Port Harcourt. This is not unconnected with the oil boom of 1975 in Nigeria. Between 1979 and 1983 additional seven federal universities of technologies were established without considering the issue of adequate funding. Initially the federal government provided $70 \%$ and the British government $30 \%$ of the total recurrent cost for the
University of Ibadan. In addition to the contribution of this funding to the university of Ibadan, the Nigerian Cocoa Marketing Board made at the outset an endowment of $\$ 1,000,000$ to the Faculty of Agriculture while the United African Company(UAC) also made donations for the building of a hall now known as Trenchard hall. The University of Nigeria Nsukka also benefitted from funding University of Michigan in addition to that of Eastern Nigerian marketing Board.

The polytechnics are typical product of post civil war phenomenon in Nigeria. Although they do not offer degree program just like universities do, from 1973 to 1982 about $80 \%$ of federal polytechnic and $90 \%$ state polytechnics were established in Nigeria. Two factors may be attributed to this trend. Acute shortage of intermediate technical manpower which constituted a bottlenecks to projects execution in the first, second and third national development plans. The second factor was the lack of conducive environment of oil wealth and investment. By 2006 there were 254 higher education institutions comprising of universities (federal, state and private), polytechnics and colleges of educations.

Recently, licenses have been granted to individuals, corporate bodies and religious bodies to establish private universities in the country. The National Universities Commission (NUC) is the major accreditation body that enforces uniform standard and sets admissions capacity of every university in Nigeria.

The development of the higher institutions in Nigeria could be seen in the number of tertiary institutions and graduate turnout after 51 years of independence. The number of universities rose from 1 to 38 in 2000, 26 of which are controlled by the federal government while 10 are state owned. By 1989/90 academic session, graduate turnout in the universities stood at 40,094, which increased to 46454 by $1993 / 94$ session. The polytechnics and colleges of education have increased in number in 1995/1996 academic session as well as the graduate turnout. This has coincided with reduction in graduate turnout at university levels and may be because of incessant academic staff strike and school closure.

In Economics, various theories have been advanced to explain the rational for higher education demand. Among the key factors explaining these trends are cost, availability of income, future earnings expectation, and employment opportunities. Studies on the demand for higher education have increased since the pioneering work of Campbell and Siegel in 1967. Although the work is not very elaborate but very important as far as factors explaining the demand for education is concerned. Their paper focuses mainly on the relationship between price and enrolment in higher education and they highlighted amongst others that the fluctuation in ratio which have taken place are associated with fluctuation in disposable income per family and constitute an index of function as deflated by the consumer price index. Albert [2], Oni [6], Adeyemi [1], Okuwa [5] tried to explain and analyze the demand for higher education in various part of the world.

Albert [2] asserted in a paper on the demand for higher education in Spain using discrete choice model that two key factors explain the high demand for higher education in the study area. These two key factors are grouped into one: family characteristics, and labor market, educational 
attainment of parents particularly mother's level of education which is more important than that of the father. The second key factor according to Albert is the labor market signal in Spain which includes labor demand, labor supply, wage income, labor acts and labor laws.

Oni [6] also analyzed the relationship between demand for university education and employer's assessment of university graduate skills in Nigeria. He found that the relationship between the above mentioned variables is weak and that university graduates do not generally possess the required skills, technical expertise, attributes required by the employers towards the attainment of their organizational goals. He concluded that more training is required to upgrade the quality of university graduate in Nigeria to fill in the position and achieve organizational requirements.

Juan De Dios Jimenez and Manuel Salas -Velasco [3] is another important study on what determine the choice for university degree course. Using binomial Logistic regression model, the study revealed that in addition to utility maximization of a rational consumer there is a basket of variables significantly important in explaining the demand for university degree in the study area. These variables include amongst others social background, family earnings and scholastic ability explains mainly the educational choice of students.

From the above literature, what is important to consider in investigating the relationship between students performance, job requirement, and choice of degree course as well as organizational goals is a combination of variables. These include among others, mother's educational attainment, family characteristics and labor markets. Note that a household (may be a consumer, producer, or wage income earner).

\section{Theoretical Framework}

There are basically two main approaches to the problem of comparison of utilities namely the cardinalist and the ordinalist approach. The cardinalist approach postulated that utility can be measured while the ordinalist school opined that utility cannot be measured.Demand for a good or service is multivariate, multidimensional and varies over time and space. Broadly speaking demand for a particular good is a function of its own price, consumer's income, price of other goods, tastes, policy, lead and lag variables [5].

In the case of education, the demand and supply determine the equilibrium position of the individual under consideration. The consumer utility maximization model of the theory of demand was therefore adopted in this paper rather than the elasticity concept because its captures the households or individual consumer in his choice of a particular good.

\subsection{Methodology}

Okuwa [5] has conducted similar study in Ibadan Oyo state using revealed preference principle. To our knowledge there is no comprehensive study on the demand for higher education in Borno State, this leaves a knowledge gap needed to be filled in. The objective of this paper is to investigate the determinant of the demand for higher education in Nigeria with a special focus in Borno State.

The revealed preference principle as in Samuelson (1948), Hicks (1950), was built on the fact that one basket of commodities is preferred to another if the consumer chooses in preference to another combination based on cost effectiveness and affordability. One of the uniqueness of the theory is that if one basket of goods is preferred to the second basket of goods, and the second revealed to the third one, then the third one must never be revealed to be preferred to the first one. In a nutshell, a private household is faced with a basket of goods yielding satisfaction at various costs within stipulated time in a competitive labor market.

\subsection{Data Resource}

Primary and secondary sources of data were used in this paper. Primary source were obtained from random distribution of 2000 questionnaires across 27 local government of Borno State. Secondary data was obtained from the Federal Bureau of statistics as well as World Bank Group website.

The paper first of all used the probabilistic sampling technique in collecting the data. The state was divided into three senatorial districts namely Borno central, Borno North and Borno South. Then the enumeration areas were identified in each local government area as the first stage. The household unit purposely selected in the local government area is the second stage. The paper then grouped households into rural and urban and each constitutes a stratum. According to National Bureau of Statistics 1997/1998 general household surveys, there are 200 enumeration areas in Borno State. A total of fifty enumeration areas were chosen and covered in this paper.

The 2000 questionnaires were administered using purposive and convenient sampling technique to 50 Enumeration Areas (EA) chosen. A total of 40 households were chosen in each local government area. Heads of Households (male or female) in both urban and rural areas were chosen to fill the questionnaires adopted from World Bank Living Standard Measurement Surveys and adapted to suit the study area.

\subsection{Model Specification}

The model for this paper is adopted from the work of Lopez-Acevado and Salinas (1998), Okuwa [5] where they considered the marginal willingness to pay and determinant of enrolment in Mexico. A utility maximizing model of school enrolment decisions was specified which will yield an empirical specification of the demand for schooling. This work assumes that every household has a utility function, which depends on the human capital of its children and the composition of all other goods and services. An investment in another year of schooling raises a child's human capital at the cost of reduced consumption of other good $\mathrm{s}$ and services. Thus, this paper was based on the assumption that parents are faced with two choices:

i. Sending their children to public higher schools and

ii. Sending their children to private higher institution.

Parents compare the utility attained from the two options listed earlier and choose the option with the higher 
utility. This paper adopt the model by specifying the utility obtained from each option. Hence, let the conditional utility of sending a child to school be given as:

$$
\mu_{\mathrm{i}}=\mu\left(\mathrm{S}_{\mathrm{i}}, \mathrm{C}_{\mathrm{i}}\right)+\epsilon_{\mathrm{i}}, \mathrm{i}=\mathrm{P}, \mathrm{PV} *
$$

Where $S_{\mathrm{i}}=$ increment to a child's human capital from another year of schooling

$\mathrm{C}_{\mathrm{i}}=$ possible consumption after incurring both the direct and indirect cost and $\epsilon_{\mathrm{i}}=$ random taste shifter, $\mathrm{P}=$ and $\mathrm{Pv}=$ private and public higher institutions.

The decision to send a child to school depends on the quality of education received because in literature Okuwa [5] discovered that the quality of schooling is an important determinant of wages.

However, both options of schooling have associated budget constraint of the form

$$
\mathrm{C}_{\mathrm{i}}+\mathrm{P}_{\mathrm{i}}^{*}=\mathrm{C}_{0}=\mathrm{Y}, \mathrm{i}=\mathrm{P}^{*}, \mathrm{Pv}^{*}
$$

where $\mathrm{P}^{*}=$ prices of sending child to public higher institutions

$\mathrm{Pv}^{*}=$ prices of sending child to private higher institutions and

$\mathrm{Y}=$ Yearly family disposable income.

The price of schooling involves both direct and indirect costs, direct cost include school fees, outlays for textbooks, stationary while the indirect cost is the opportunity cost for children time.

The unconditional utility maximization problem is stated below as

$$
\mathrm{U}^{*}=\operatorname{Max}\left(\mathrm{U}_{\mathrm{i}}, \mathrm{U}_{\mathrm{s}}\right)
$$

Where $\mathrm{U}^{*}=$ maximum utility

$\mathrm{U}_{\mathrm{i}}=$ and $\mathrm{U}_{\mathrm{s}}=$ the conditional utitlity functions specified in equation 1 given the constraint in equation 2 .

Solving the utility maximization problem there is a system of demand functions whose forms are probabilities that the alternatives are chosen. The probability that any alternative is chosen equals the probability yields the highest utility amongst all the alternatives. The functional form of the demand functions depend on that of the conditional utility function and that on the distribution of the stochastic variables. Thus after rearranging, the conditional utility function for the two schooling options be:

$$
\mathrm{U}_{\mathrm{i}}=\alpha_{0} \mathrm{~S}_{\mathrm{i}}+\alpha_{1} \mathrm{C}_{\mathrm{i}}+\alpha_{2} \mathrm{C}_{\mathrm{i}}^{2}+\epsilon_{\mathrm{i}}
$$

Where each $\epsilon_{\mathrm{i}}$ is a zero mean random taste disturbance with finite variance and is uncorrelated across individuals.

Rearranging equation 2 to get

$$
\mathrm{C}_{\mathrm{i}}=\mathrm{Y}-\mathrm{P} *_{\mathrm{i}}=\mathrm{Y}-\mathrm{P}_{\mathrm{i}}-\mathrm{wH}_{\mathrm{i}} ; \mathrm{i}=\mathrm{P}, \mathrm{Pv}
$$

Substituting equation 5 into equation 4 to get

$$
\begin{aligned}
\mathrm{U}_{\mathrm{i}}= & \alpha_{0} \mathrm{~S}_{\mathrm{ii}}+\alpha_{1}\left(\mathrm{Y}-\mathrm{P} *_{\mathrm{i}}=\mathrm{Y}-\mathrm{P}_{\mathrm{i}}-\mathrm{wH}_{\mathrm{i}}\right) \\
& +\alpha_{2}\left(\mathrm{Y}-\mathrm{P}_{\mathrm{i}}-\mathrm{wH}_{\mathrm{i}}\right)^{2}+\epsilon_{\mathrm{i},}, \mathrm{i}=\mathrm{P}, \mathrm{Pv}
\end{aligned}
$$

Where $\mathrm{Ui}=$ utility derived from sending the child to either a public $(\mathrm{i}=\mathrm{P})$ higher institution or private $(\mathrm{i}=\mathrm{Pv})$ institution.

The identification of the parameters in equation (6) requires that the values of human capital and consumption differ depending on the alternatives. The alternative chosen is the one that yields the highest utility.

Pollak and watchter (1975) opined that the separate effects of demographic variable in the production of human capital and in the marginal utility function cannot be identified. We therefore specify a reduced form model of the utility function from human capital. Let the utility function from human capital be given as :

$$
\alpha_{0} \mathrm{~S}_{\mathrm{i}}=\mathrm{Y}_{\mathrm{i}} \mathrm{X}_{\mathrm{i}}+\mathrm{n}_{\mathrm{i}}
$$

where $X_{i}=$ vector of school, family, quality, and demographic characteristics.

Rearranging and substituting equation 7 into the conditional utility function 6 yields:

$$
\begin{gathered}
\mathrm{U}_{\mathrm{i}}=\mathrm{Y}_{\mathrm{i}} \mathrm{X}_{\mathrm{i}}+\mathrm{n}_{\mathrm{i}}+\alpha_{1}\left(\mathrm{Y}-\mathrm{P}_{\mathrm{i}}-\mathrm{wH}_{\mathrm{i}}\right) \\
+\alpha_{2}\left(\mathrm{Y}-\mathrm{P}_{\mathrm{i}}-\mathrm{wH}_{\mathrm{i}}\right)^{2}+\epsilon_{\mathrm{i}} \\
\mathrm{U}_{\mathrm{i}}=\mathrm{V}_{\mathrm{i}}+\epsilon_{\mathrm{i}}+\mathrm{n}, \mathrm{i}=\mathrm{P}, \mathrm{Pv} .
\end{gathered}
$$

\subsection{Results and Discussions}

The Probit regression model is used to estimate the demand function specified in equation 8 .

The result of probit regression in Table 1 shows the determinants of the demand for higher education in Borno State. The binary choice model assumes that individuals are faced with a choice between two alternatives and that the choices depend on characteristics and each of the estimators represent the respondents' views about the issue of education.

Table 1. Probit estimation results of demand for higher education in Borno State

\begin{tabular}{|l|c|c|c|}
\hline Variable(private) & Coefficient & $\mathbf{Z}$ value & P value \\
\hline Age & -0.14 & -1.23 & 0.24 \\
\hline Household size & -0.80 & -2.2 & 0.04 \\
\hline School fee & 0.03 & 2.38 & 0.00 \\
\hline Father's education & 0.03 & 1.7 & 0.03 \\
\hline Mother's education & 0.02 & -1.53 & 0.19 \\
\hline Own house & 0.33 & 0.53 & 0.65 \\
\hline Rural & -0.50 & -4.29 & 0.00 \\
\hline Female & 0.50 & 0.53 & 0.62 \\
\hline Strike & 0.40 & 5.02 & 0.00 \\
\hline Constant & -1.6 & -3.48 & 0.00 \\
\hline per capita expenditure & 0.07 & 1.3 & 0.02 \\
\hline
\end{tabular}

Sources: Author's computation from field survey.

Sample Size: 1,912

$\operatorname{LR} \operatorname{chi}^{2}(10)=39.94$

Prob> chi $^{2}=0.000$

Pseudo $\mathrm{R}^{2}=0.006$

Log likelihood $=-437.95719$.

The dependent variable is when enrolment into private higher education is equal to 1 . The household demand for private higher education is highly dependent on per capita expenditure, father's educational status, school fees, gender and Academic staff union of universities strikes. The results also reveal that all coefficients have the 
expected sign and the coefficients magnitude are also robust.

The coefficient of per capita expenditure and school fees a have a probability values of 0.02 and 0.00 respectively implying statistical significance level of 5 per cent. So also the coefficient sign. By implication if the log per capita expenditure of a particular household increases by 0.02 , the demand for higher private education will increase by the same percentage point. That is to say there is one to one relationship between the dependent variable and the independent variable in the estimated model. The same explanation applies to the variable school fees which moves in the same direction with the demand for private higher education. The estimation result also reveals that while father's education is significant at $5 \%$ level the mother's educational attainment is statistically insignificant at that level. More so the two variables' sign are consistent with expectation. This result agrees with the papers of Mingat, Lee, and Tan [4], Okuwa [5] that showed a positive relationship between parents educational background and ability and willingness (demand) for higher private education.

The coefficient of household is located in the rural area although significant on the regressand at $5 \%$ level but inversely related to the demand for private education in the State. This is due to the fact that most rural households are either unskilled (had no formal education), semi skilled (completed primary school) or skilled (had gone through tertiary institution) and that the lower the level of education the most likely is for the children not to demand for private higher education and vice versa.

The strike of academic staff union of universities is another variable of interest in this paper. The result shows that the variable is significant at $5 \%$ and consistent with expectation. The longer the strike duration, the increase the demand for higher private education for urban, male headed household and highly educated parents.

Conclusively, the households demand for private tertiary education is positively influenced by per capita expenditure or consumption expenditure of the head of household, school fees, father's level of education, household assets or wealth (owning a house), gender and University teachers' strike.

The Probability value shows that strike, location of households (either in urban or rural area)and school fees are highly statistically significant in explaining the demand for private higher education in Borno State. Moreover, the household size, the log per capita expenditure (determinant of poverty), the father's education also influence the decision of the household respondents for private tertiary education in the state. It is worth noting that variables strike of university teachers, school fees and location of households are the most strongly statistically significant in the model specified.

Table 2 shows the probit estimation result for rural households demand for private tertiary institution in Borno state. School fees, strike, household per capita expenditure, parents education level, asset ownership (owning a house) positively influence the choice of higher education by rural households members. However, the size of households (in terms of children in the family), the level of poverty, the strike action of academic staff of public universities significantly statistically affect the demand for higher education in the rural areas in Borno State. That is to say if strike increases by 44 per cent the demand for private higher education by rural respondents will increase by the same percentage. The same scenario applies to household size. If the households size in the rural area increase by 28 percent it will negatively affect the demand for higher education in the same households because more resources are committed to the maintenance of household members instead of paying school fees to selected family members.

Table 2. Probit of the demand for higher education by rural headed households

\begin{tabular}{|l|c|c|c|}
\hline Variable(Private) & Coefficient & $\mathbf{Z}$ value & P value \\
\hline Age & -0.13 & -0.60 & 0.53 \\
\hline Household Size & -0.28 & -3.54 & 0.00 \\
\hline Per capita expenditure & 0.04 & -1.29 & 0.03 \\
\hline School fees & 0.02 & 1.59 & 0.11 \\
\hline Father's education & 0.02 & 0.53 & 0.62 \\
\hline Mother's education & 0.01 & 0.30 & 0.88 \\
\hline Own house & 0.25 & 1.17 & 0.42 \\
\hline Female & -0.09 & -0.6 & 0.65 \\
\hline Strike of academic staff & 0.44 & 2.09 & 0.04 \\
\hline Constant & -1.37 & -1.98 & 0.08 \\
\hline
\end{tabular}

Sources: Author's computation, 2013.

Sample size: 777

LR Ch square: 20.50

Prob> chi square: 0.0001

Pseudo $\mathrm{R}^{2}: 0.12$

Log likelihood: -86.9425 .

The coefficient of household per capita shows a positive relationship where 4 percent increase in expenditure brings about a change in the demand for higher education in the same household.

Table 3. Estimation result of the demand for higher education by rural households respondents

\begin{tabular}{|l|c|c|c|}
\hline Variable (private) & Coefficient & Z value & P value \\
\hline Age & -0.19 & -1.6 & 0.086 \\
\hline Household size & -0.03 & 0.85 & 0.54 \\
\hline Per capita expenditure & 0.1 & -0.67 & 0.46 \\
\hline School fees & 0.04 & 3.34 & 0.002 \\
\hline Father's education & 0.03 & 1.06 & 0.234 \\
\hline Mother's education & 0.04 & -1.23 & 0.324 \\
\hline Own house & 0.03 & 0.26 & 0.87 \\
\hline Female & 0.000 & 0.005 & 0.97 \\
\hline Strike & 0.43 & 3.867 & 0.00 \\
\hline Constant & -1.46 & -4.72 & 0.00 \\
\hline
\end{tabular}

Sources: Author's computation

Sample Size: 1,254

LR chi square(10) 31.3

Prob $>$ chi $^{2}=0.000$

Pseudo $\mathrm{R}^{2}=0.043$ Log likelihood:-373.15105.

The regression output for urban households followed similar pattern for all respondents and rural households except for the variable gender with a coefficient having a 
positive sign. This is contrary to what was obtained in the estimation output in rural households case where the coefficient of female household has a negative sign. Also, strike and school fees significantly statistically positively influence the choice of private tertiary institution of urban households in Borno state of Nigeria. The findings of the estimation results is consistent with the work of LopezAcevado and Salinas (1998). The paper also confirmed the probit estimation results of Okuwa [5] in Oyo state of Nigeria.

\section{Conclusion, Policy implication and area for further research}

This paper has investigated the determinants of the demand for private education in Borno state using probit regression model technique. Specifically the result shows that the size of households, per capita spending, school fees, father's level of education, households location in the rural or urban areas, and intermittent strikes of university teachers constitute the main determinants of higher education demand in Borno state. Note that high increase in the demand for higher private institution in Borno state can be attributed to the influence of institutional, economic and socio cultural factors. Another demand determining factor is the strike in public institutions experience in the last two decades with very adverse effects on the smooth running on academic activities of public institutions of higher learning.

\section{Policy Implications}

This decade has experienced an increase in the post secondary education participation. This has been a major source of concern for acedemics, policy makers and planners.

Demand for Private higher education has contributed to the development of private institutions of higher learning generally producing low quality graduates with little skills to compete in the labor market. So measures should be put in place by educational planners to emphasize the quality of output from the higher public and private institutions.

- There is also need to match the candidate choice of course and the marketability of the course in the labor market.

- This paper also that school fee is never an impediment to choosing the private higher institution.
Therefore user charges could be used to address poor funding of public institutions in Nigeria.

- Policy makers should look into agitations of lecturers in tertiary public institutions in order to address the teething problem of inadequate funding of public institutions to avoid brain drain and further falling standard of education in Nigeria.

\section{Areas for further research}

Below are some key areas that need further investigation:

- What is the causality between higher demand for private institution and quality of graduate turn out in Nigeria?

- How can we use backward and forward linkages to explain the quality of graduate in the Nigerian higher institutions of learning?

- What is the relationship between female headed household, located in the rural areas and the demand for higher private education in Nigeria?

- Is there any cointegration relation between strikes of university lecturers and falling standard of education in Nigeria?

- Is the labor market able to absorb the ever increasing graduate turn out?

\section{References}

[1] Adeyemi, K. (2001). Equality of access and catchment area factor in university admissions in Nigeria. Higher Education, 307-332.

[2] Albert, C. (2000). Higher Education Demand in Spain: The influence of Labor market signal and family background. Higher Education, 40,147-162

[3] Juan de Dios Jimanez., \& Mannel Salas-Valasco. (2000). Modelling Educational choices. A binomial logit Model applied to the demand for higher education. 293-311.

[4] Mingat, A., Kiong, H.L., \& Jee-peng, T. (1984) User charges for education: The ability and willingness to pay in Malawi, World Bank Staff Working Paper no.661. Washington. D.C.

[5] Okuwa, O.B. (2009). Binomial analysis of the Demand for Higher Education in Oyo State, Nigeria. Journal Of Applied Econometrics and Macroeconometric Modelling in Nigeria.503-519.

[6] Oni, B. (2000). The demand for university graduate and employer assessment of graduate skills in Nigeria. Nigerian Institute of Social and Economic Research (NISER), Ibadan. 